\title{
EFFECT OF IRRIGATION INTERVALS AND NITROGEN FERTILIZER RATE ON GROWTH, YIELD AND CHEMICAL COMPOSITION OF Ricinus communis L. UNDER NORTH SINAI CONDITIONS
}

(Received:15.11.2009)

\author{
A. S. El-Leithy, H. M.F. Swaefy, A. M.A. Badawi *, \\ G. F. Ahmed and T. I. M. Dawood*
Ornamental Horticulture Department, Faculty of Agricultural, Cairo University, Giza, Egypt. *Cultivation and Production of Medicinal and Aromatic plants Department, Desert Research Center, Cairo, Egypt.

\begin{abstract}
A field experiment was conducted, during 2004/2005 and 2005/2006, at the Experimental Field and Laboratories of North Sinai Research Station, Desert Research Centre, at El-Sheikh Zowayed, North Sinai Governorate, Egypt to investigate the effect of irrigation intervals (every 10, 15, 30 days, and rainfed treatment) and nitrogen fertilizer rates $(0,100,200$, and $300 \mathrm{~kg} / \mathrm{fed} . / \mathrm{season}$ as ammonium sulphate) on vegetative growth, seed yield, fixed oil production and chemical composition of Ricinus communis L.

Data indicated that irrigation every 10 days significantly increased vegetative growth (plant height and herb fresh and dry weights), seed yield/ plant, seed index, oil yield per plant and per feddan, total carbohydrates and $\mathrm{N}$ contents in the leaves compared with rainfed or irrigation every 30 days which gave the lowest values.

Nitrogen fertilization at $300 \mathrm{~kg} /$ fed significantly increased plant height, fresh and dry weights/ plant, seed yield/ plant, seed index, fixed oil yield/ plant and per fed., total carbohydrates and $\mathrm{N}$ contents in the leaves in both seasons.

The combined effect between irrigation every 10 days and nitrogen fertilization at $300 \mathrm{~kg} /$ fed gave the highest values of plant height, fresh and dry weights/ plant, seed yield/ plant, seed index, fixed oil yield/ plant and per fed. and total carbohydrates contents in the leaves in both seasons, while the rainfed treatment combined with the unfertilized control gave the lowest values.
\end{abstract}

Key words: fixed oil, irrigation, nitrogen fertilization, Ricinus commanis.

\section{INTRODUCTION}

Castor bean (Ricinus communis L.) is a subtree belonging to the family Euphorbiaceae which is a large family of 240 genera and around 6,000 species. Probably native to Africa, castor bean has been introduced and is cultivated in many tropical and subtropical areas of the world, frequently appearing spontaneously. Plants grow best on fertile, well-drained soils which are neither alkaline nor saline; sandy and clay loam being best. Fruits are harvested when fully mature, in about 95-180 days depending on the cultivar. Castor bean is cultivated for the seeds which yield fast-drying, non-yellowing oil, used mainly in industry and medicines. Hydrogenated oil is utilized in the manufacture of waxes, polishes, carbon paper, candles and crayons. 'Blown Oil' is used for grinding lacquer paste colors, and when hydrogenated and sulfonated is used for preparation of ointments. Castor oil pomace, the residue after crushing, is used as a high-nitrogen fertilizer (Reed, 1976). Castor bean plants could be considered anodyne, antidote, aperient, bactericide, cathartic, cyanogeneic, discutient, emetic, emollient, expectorant, insecticide, lactagogue, larvicidal, laxative, poison, purgative, tonic, etc. Ricinoleic acid has served in contraceptive jellies. Ricin, a toxic protein in the seeds, acts as a blood coagulant. Castor oil is used externally for treatment of dermatitis and eye ailments (Duke and Wain,1981).

Water affects markedly, either directly or indirectly, most plant physiological processes; Bhosekar (1992) on Ricinus communis, Ishwar and Ganpat (1992) on $R$. communis, El- Shafie et al. (1994) on roselle, Naguib and Hussein (1995) on roselle, Reddy et al. (1996) on Ricinus communis, Hammam (1996) on anise (Pimpinella 
anisum), Youssef (1997) on Cuminum cyaminum, Sidky et al. (1998) on roselle, Firake et al. (1999) on castor (Ricinus communis) cv. GAU CH-1, Mohamed (2000) on Carum carvi, Osman (2000) on coriander, Attia (2003) on guar, Akbarinia et al. (2005) on Nigella sativa, Nagabhushanam and Raghavaiah (2005) on castor hybrid DCH-177 (Deepak)].

Nitrogen fertilization affects growth, yield and active constituents of castor bean plants [ Devi et al. (1990), Patel et al. (1991), Wali et al. (1991), Bhosekar (1992), Paikaray et al. (1992), Mathukia and Modhwadia (1993, and 1995), Hikwa and Mugwira (1997), Akbari et al. (2001); Khandelwal et al. (2003) on Lawsonia inermis. Kadam et al, (2006); Lakshmi and Reddy (2006); Silva et al. (2007); Tank et al. (2007), and Venugopal et al. (2007)]

The aim of this study was to determine the effect of irrigation intervals and nitrogen fertilizer rate on growth, yield and chemical composition of Ricinus communis L. under North Sinai conditions.

\section{MATERIALS AND METHODS \\ 2.1. Field experiment}

The present study was carried out during the two successive seasons of 2004/2005 and 2005/2006 at the Experimental Field and Laboratories of North Sinai Research Station, Desert Research Centre, at El-Sheikh Zowayed, North Sinai Governorate. The objective of this work was to study the effect of irrigation intervals and nitrogen fertilization rates on growth, yield and chemical composition of Ricinus communis L.

The seeds of castor bean (Ricinus communis L.) var. red were obtained from the Egyptian Desert Gene Bank (DRC). The seeds were sown on a sandy soil on the $1^{\text {st }}$ of July 2004 and 2005, at $100 \mathrm{~cm}$ between rows and $100 \mathrm{~cm}$ between hills, in 16 treatments, each with three replicates. The replicate contained 10 plants in one row. The seedlings were irrigated using a drip irrigation system as needed until they were completely established.

The layout of the experiment was a split plot design, in which irrigation intervals represented the main plot, while nitrogen fertilization rates represented the sub plots. The treatments started four months after sowing and continued for eight months.

Four irrigation intervals were used : Rainfed (control), 10, 15 and 30 day intervals. A drip irrigation system was used, with a water discharge rate of 4L/dripper/ hour. Each plant has two drippers and each treatment was irrigated for two hours.

Ammonium sulphate $(20.5 \% \quad \mathrm{~N})$ as soil dressing was used at the rates of $0,100,200$ and $300 \mathrm{~kg} / \mathrm{fed}$. in three doses/ season. The first dose was added four months after sowing, the second dose was added after 45 days from the first and the third dose was added after 45 days from the second dose. All the plants received calcium super phosphate $\left(15.5 \% \mathrm{P}_{2} \mathrm{O}_{5}\right)$ at $100 \mathrm{~kg} /$ fed during soil preparation and potassium sulphate $\left(48 \% \mathrm{~K}_{2} \mathrm{O}\right)$ at $100 \mathrm{~kg} / \mathrm{fed}$ as a constant rate divided into two equal doses, added with the first and second doses of ammonium sulphate.

\subsection{Water and soil analysis}

Physical and chemical analysis of soil and chemical properties of irrigation water used (Tables, A and B) were analyzed as described by (Jackson, 1973).

Harvesting of the mature inflorescences was carried out from the first week of May until the last week of June.

Data on plant height, fresh and dry weights/ plant, seed yield/ plant, seed index, fixed oil percentage, fixed oil yield per plant and per fed., total carbohydrates and nitrogen contents in the dried leaves were recorded.

The fixed oil percentage in seed samples was determined adopting the Method described in A.O.A.C. (1995). Nitrogen content was determined by Micro-Kjeldahl method as described by Pregl (1945). Total carbohydrate contents were determined in the dried herb using the method described by Chaplin and Kennedy (1994).

Meteorological data for ElSheikh Zoweyed, ElArish, North Sinai regian during both season are shown in Tables (C and D).

Data recorded were statistically analyzed using the Least Significant Difference (L.S.D.) test at the 5\% level, as described by Snedecor and Cochran (1982).

\section{RESULTS AND DISCUSSION 3.1. Vegetative growth 3.1.1. Plant height}

The data in Table (1) show that irrigation intervals had a significant effect on plant height in both seasons. Irrigation every 10 days gave the tallest plants in the first and second seasons, compared with other irrigation intervals. Generally, the shortest and moderate irrigation intervals significantly increased plant height compared with rainfed treatment in both seasons. Similar results were obtained by El- Shafie et al. 


\section{Water and soil analysis}

Table (A): Mechanical and chemical properties of the used soil.

\begin{tabular}{|c|c|c|c|c|c|c|c|c|c|c|}
\hline \multicolumn{11}{|c|}{ Physical analysis } \\
\hline \multicolumn{3}{|c|}{ Fine sand \% } & \multicolumn{2}{|c|}{ Coarse sand \% } & \multicolumn{2}{|c|}{ Clay \% } & \multicolumn{2}{|c|}{ Silt \% } & \multicolumn{2}{|c|}{ Texture grade } \\
\hline \multicolumn{2}{|c|}{31.96} & & \multicolumn{2}{|c|}{58.36} & \multicolumn{2}{|c|}{2.25} & \multicolumn{2}{|c|}{7.43} & \multicolumn{2}{|c|}{ Sandy soil } \\
\hline \multicolumn{11}{|c|}{ Chemical analysis } \\
\hline \multirow[t]{2}{*}{$\mathbf{p H}$} & \multirow[t]{2}{*}{$\begin{array}{c}\text { Ec } \\
(\mathbf{d s} / \mathbf{m})\end{array}$} & \multicolumn{4}{|c|}{$\begin{array}{c}\text { Soluble cations } \\
(\mathrm{meq} / \mathrm{L})\end{array}$} & \multicolumn{3}{|c|}{$\begin{array}{c}\text { Soluble anions } \\
(\mathrm{meq} / \mathrm{L})\end{array}$} & \multicolumn{2}{|c|}{$\begin{array}{c}\text { Available elements } \\
\text { (ppm) }\end{array}$} \\
\hline & & $\mathrm{Na}^{+}$ & $\mathrm{K}^{+}$ & $\mathrm{Ca}^{++}$ & $\mathrm{Mg}^{++}$ & $\mathrm{HCO}_{3}^{-}$ & $\mathrm{Cl}^{-}$ & $\mathrm{SO}_{4}^{-}$ & $\mathrm{N}$ & $\mathrm{P}$ \\
\hline 8.47 & 0.90 & 4.50 & 0.25 & 4.08 & 0.82 & 1.91 & 3.00 & 4.74 & 12.00 & 7.00 \\
\hline
\end{tabular}

Table (B): Chemical properties of irrigation water used.

\begin{tabular}{|c|c|c|c|c|c|c|c|c|c|}
\hline \multirow{2}{*}{$\mathbf{p H}$} & \multirow{2}{*}{$\begin{array}{c}\text { Ec } \\
(\mathbf{m m h o s} / \mathbf{c m})\end{array}$} & \multicolumn{3}{|c|}{$\begin{array}{c}\text { Soluble cations } \\
(\mathbf{p p m})\end{array}$} & \multicolumn{4}{c|}{$\begin{array}{c}\text { Soluble anions } \\
(\mathbf{p p m})\end{array}$} \\
\cline { 3 - 11 } & & $\mathbf{C a}^{++}$ & $\mathbf{M g}^{++}$ & $\mathbf{N a}^{+}$ & $\mathbf{K}^{+}$ & $\mathbf{C O}_{3}^{--}$ & $\mathbf{H C O}_{3}^{-}$ & $\mathbf{C l}^{-}$ & $\mathbf{S O}_{4}^{-{ }^{-}}$ \\
\hline 8.3 & 0.620 & 41.02 & 24.92 & 55.0 & 2.00 & 23.22 & 86.55 & 85.50 & 89.00 \\
\hline
\end{tabular}

Table (C): Meteorological data for El-Sheikh Zowayed, El-Arish, North Sinai during 2004/2005 season.

\begin{tabular}{|c|c|c|c|c|c|}
\hline \multirow{2}{*}{ Month } & $\begin{array}{c}\text { Avg.Temp } \\
\left({ }^{\circ} \mathbf{C}\right)\end{array}$ & Et. $(\mathbf{m m})$ & $\begin{array}{c}\text { Avg. Ws } \\
(\mathbf{K m} / \mathbf{h})\end{array}$ & $\begin{array}{c}\text { Total Rain } \\
(\mathbf{m m})\end{array}$ & RH $(\mathbf{\%})$ \\
\hline $\mathbf{7}$ & 25.774 & 3.505 & 12.766 & ---- & 94.619 \\
\hline $\mathbf{8}$ & 26.064 & 3.192 & 13.378 & ---- & 91.99 \\
\hline $\mathbf{9}$ & 25.023 & 1.427 & 10.009 & ---- & 88.516 \\
\hline $\mathbf{1 0}$ & 23.137 & 0.941 & 10.803 & 0.762 & 95.238 \\
\hline $\mathbf{1 1}$ & 18.933 & 0.704 & 14.313 & 75.946 & 90.161 \\
\hline $\mathbf{1 2}$ & 13.199 & 0.568 & 11.383 & 99.314 & 88.49 \\
\hline $\mathbf{1}$ & 13.032 & 0.791 & 16.484 & 53.594 & 86.465 \\
\hline $\mathbf{2}$ & 13.439 & 0.867 & 16.165 & 38.862 & 87.023 \\
\hline $\mathbf{3}$ & 15.834 & 1.289 & 12.896 & 28.702 & 88.023 \\
\hline $\mathbf{4}$ & 18.198 & 1.712 & 15.085 & 2.540 & 86.196 \\
\hline $\mathbf{5}$ & 20.177 & 2.064 & 13.351 & --- & 91.432 \\
\hline $\mathbf{6}$ & 23.531 & 2.455 & 12.346 & --- & 94.297 \\
\hline
\end{tabular}

Et = Evapotranspiration; Ws = Wind speed; RH = Relative humidity

Table (D): Meteorological data for El-Sheikh Zowayed, El-Arish, North Sinai during 2005/ 2006 season.

\begin{tabular}{|c|c|c|c|c|c|}
\hline Month & $\begin{array}{c}\text { Avg Temp } \\
\mathbf{(} \mathbf{C})\end{array}$ & $\mathbf{E t}(\mathbf{~ m m})$ & $\begin{array}{c}\text { Avg Ws } \\
(\mathbf{K m} / \mathbf{h})\end{array}$ & $\begin{array}{c}\text { Total Rain } \\
(\mathbf{m m})\end{array}$ & $\mathbf{R H}(\mathbf{\%})$ \\
\hline $\mathbf{7}$ & 25.702 & 2.461 & 12.913 & ---- & 97.649 \\
\hline $\mathbf{8}$ & 26.784 & 1.857 & 12.014 & ---- & 94.995 \\
\hline $\mathbf{9}$ & 25.636 & 1.43 & 11.983 & 1.016 & 91.137 \\
\hline $\mathbf{1 0}$ & 22.422 & 0.655 & 11.858 & ---- & 88.11 \\
\hline $\mathbf{1 1}$ & 17.673 & 0.365 & 12.485 & 22.86 & 86.836 \\
\hline $\mathbf{1 2}$ & 15.261 & 0.176 & 10.543 & 27.178 & 95.073 \\
\hline $\mathbf{1}$ & 12.931 & 0.459 & 13.648 & 26.67 & 93.066 \\
\hline $\mathbf{2}$ & 13.931 & 0.490 & 13.325 & 49.022 & 92.46 \\
\hline $\mathbf{4}$ & 15.513 & 0.634 & 13.053 & 1.524 & 90.248 \\
\hline $\mathbf{5}$ & 18.24 & 1.435 & 14.526 & 27.686 & 93.704 \\
\hline $\mathbf{6}$ & 20.179 & 2.511 & 11.732 & --- & 98.144 \\
\hline
\end{tabular}

Et = Evapotranspiration; Ws = Wind speed; RH = Relative humidity 
(1994) on roselle, Hammam (1996) on anise, Osman (2000) on coriander, Attia (2003) on guar, Akbarinia et al. (2005) on black cumin, Nagabhushanam and Raghavaiah (2005) on castor bean plants.

Nitrogen fertilization rate had a significant zffect on plant height in the first season. Plant height gradually increased with increasing $\mathrm{N}$ rate. Whereas in the second season, nitrogen ertilization had no significant effect on plant height compared with the control. These results are in harmony with those obtained by Khandelwal et al. (2003) on Lawsonia inermis. They showed that increasing nitrogen rate increased plant height.

Concerning the interaction effect between irrigation intervals and $\mathrm{N}$ fertilization rates, the data revealed that the interaction had a significant effect on plant height. In both seasons, irrigation every 10 days and fertilization with $\mathrm{N}$ at 300 $\mathrm{kg} / \mathrm{fed}$ gave the tallest plants, whereas rainfed treatment combined with no fertilizer (control) in the first season, and rainfed treatment combined with $\mathrm{N} 2$ in the second season gave the shortest plants.

\subsubsection{Fresh and dry weights per plant}

Data in Tables (2 and 3) indicate that plant fresh and dry weights were increased as the water irrigation intervals decreased. All irrigation treatments significantly increased plant fresh and dry weights/ plant. Irrigation every 30 days insignificantly increased fresh and dry weights/ plant in both seasons. While the shortest irrigation interval (10 days) gave the highest fresh and dry weights/ plant compared with the rainfed treatment in both seasons. Similar results were obtained by El- Shafie et al. (1994) on roselle, Hammam (1996) on anise, Sidky et al. (1998) on roselle, Mohamed (2000) on Carum carvi, Osman (2000) on coriander, Attia (2003) on guar; Akbarinia et al., (2005) on Nigella sativa, Nagabhushanam and Raghavaiah (2005) on castor bean. They showed that prolonging irrigation intervals decreased plant fresh and dry weights.

Concerning the effect of nitrogen fertilizer rates, the data show that, in the first season, no significant differences were recorded between N1 and $\mathrm{N} 2$ fertilization treatments and the control Meanwhile, the highest nitrogen rate (N3) gave significantly higher plant fresh and dry weights/ plant, compared with lower $\mathrm{N}$ rates. In the second season, raising nitrogen fertilization rates gradually increased plant fresh and dry weights with significant differences between the control and the highest nitrogen fertilizer rate (N3). These results are in agreement with those obtained by
Khandelwal et al. (2003) on Lawsonia inermis, who showed that the highest fresh and dry weights/ plant were obtained by nitrogen application at $120 \mathrm{~kg} / \mathrm{ha}$.

The interaction between irrigation intervals and nitrogen fertilizer rates had a significant effect on plant fresh and dry weights in both seasons. Combining irrigation every 10 days with the highest nitrogen rate $(\mathrm{N} 3)$ gave the highest fresh and dry weights plant in the first and second seasons. On the other hand, the lowest fresh weight was obtained with rainfed treatment combined with N1 treatment, while the lowest dry weights/plant were obtained with rainfed treatment combined with no nitrogen fertilization (N0) in the two seasons.

\subsection{Seed production}

\subsubsection{Seed yield}

The data presented in Table (4) show that, plants which depended on rain for their water requirement produced the lowest seed yield/plant with values of (16.52 and $16.33 \mathrm{gm} / \mathrm{plant})$ in the two seasons, respectively. Irrigation every 30 days insignificantly increased seed yield per plant in the first and second seasons compared to rainfed system. Decreasing irrigation intervals from 30 days to 10 or 15 days significantly increased seed yield/plant compared to the rainfed system. The highest seed yield per plant was obtained from plants irrigated every 10 days. These results are in harmony with those obtained by Bhosekar (1992); Ishwar and Ganpat (1992); Reddy et al., (1996); Firake et al., (1999); Nagabhushanam and Raghavaiah (2005) on castor bean; Mohamed (2000) on Carum carvi; Osman (2000) on coriander; Attia (2003) on guar and Akbarinia et al., (2005) on Nigella sativa.

Nitrogen fertilization using either low or medium rates insignificantly increased seed yield per plants compared to unfertilized plants in both seasons. While using the highest nitrogen rate (N3) gave the highest seed yield per plant (54.65 and $55.17 \mathrm{gm} /$ plant in the two seasons, respectively) compared to the unfertilized treatment, which gave 23.05 and $23.23 \mathrm{gm} /$ plant in both seasons, respectively. Similar results were obtained by Patel et al. (1991), Wali et al. (1991), Bhosekar (1992), Paikaray et al. (1992), Mathukia and Modhwadia (1993), Hikwa and Mugwira (1997), Akbari et al. (2001), Kadam et al. (2006), Silva et al. (2007), Tank et al. (2007) and Venugopal et al. (2007). They found that applying nitrogen fertilization to castor plants at the highest rates gave the highest seed yield.

Regarding the effect of the interaction between 
Table (1): Effect of irrigation intervals and nitrogen fertilization on plant height (cm) of Ricinus communis $\mathbf{L}$. plants during 2004/2005 and 2005/2006 seasons.

\begin{tabular}{|c|c|c|c|c|c|}
\hline \multirow{2}{*}{$\begin{array}{l}\text { Nitrogen rates } \\
\text { Irrigation treatments }\end{array}$} & \multicolumn{5}{|c|}{ First Season, 2004/2005 } \\
\hline & No & N1 & N2 & N3 & Mean \\
\hline Rainfed & 87.76 & 107.00 & 113.40 & 117.50 & 106.42 \\
\hline 10 days & 151.00 & 150.90 & 145.30 & 159.00 & 151.55 \\
\hline 15 days & 124.40 & 130.80 & 119.60 & 128.80 & 125.90 \\
\hline 30 days & 95.48 & 108.60 & 111.60 & 102.00 & 104.42 \\
\hline Mean & 114.66 & 124.33 & 122.48 & 126.83 & \\
\hline \multicolumn{6}{|c|}{$\begin{array}{lll}\text { L.S.D. at } 0.05 \text { for: } & & \\
\text { Irrigation intervals } & \text { (A) } & 9.06 \\
\text { N fertilization } & \text { (B) } & 9.06 \\
\text { Interaction } & \text { (AXB) } & 18.11\end{array}$} \\
\hline \multicolumn{6}{|c|}{ Second Season, 2005/2006 } \\
\hline Treatments & No & N1 & $\mathbf{N 2}$ & N3 & Mean \\
\hline Rainfed & 79.01 & 89.50 & 69.39 & 87.83 & 81.43 \\
\hline 10 days & 117.30 & 104.90 & 135.80 & 157.50 & 128.88 \\
\hline 15 days & 116.90 & 129.40 & 128.70 & 138.90 & 128.48 \\
\hline 30 days & 112.10 & 108.20 & 86.92 & 107.80 & 103.76 \\
\hline Mean & 106.30 & 108.00 & 105.20 & 123.00 & \\
\hline $\begin{array}{l}\text { L.S.D. at } 0.05 \text { for: } \\
\text { Irrigation intervals (A) } \\
\text { N fertilization rate (B) } \\
\text { Interaction } \quad(\mathbf{A X B})\end{array}$ & $\begin{array}{l}18.64 \\
18.64 \\
37.28\end{array}$ & & & & \\
\hline
\end{tabular}

Table (2): Effect of irrigation intervals and nitrogen fertilization on fresh weight (gm) per plant of Ricinus communis L. plants during 2004/2005 and 2005/2006 seasons.

\begin{tabular}{|c|c|c|c|c|c|}
\hline \multirow{2}{*}{$\begin{array}{l}\text { Nitrogen rates } \\
\text { Irrigation treatments }\end{array}$} & \multicolumn{5}{|c|}{ First season, 2004/2005 } \\
\hline & No & N1 & $\mathbf{N 2}$ & $\mathbf{N 3}$ & Mean \\
\hline Rainfed & 300.0 & 298.3 & 358.3 & 546.3 & 375.8 \\
\hline 10 days & 763.3 & 1500.0 & 1360.0 & 2900.0 & 1631.0 \\
\hline 15 days & 2140.0 & 780.0 & 896.7 & 1150.0 & 1242.0 \\
\hline 30 days & 390.0 & 394.0 & 489.0 & 1012.0 & 571.2 \\
\hline Mean & 898.3 & 743.1 & 776.0 & 1402.0 & \\
\hline \multicolumn{6}{|c|}{$\begin{array}{lll}\text { L.S.D at } \mathbf{0 . 0 5} \text { for: } & & \\
\text { Irrigation intervals (A) } & 588.3 \\
\text { N fertilization rate (B) } & 588.3 \\
\text { Interaction } & \text { (AXB) } & 1177.0\end{array}$} \\
\hline \multicolumn{6}{|c|}{ Second season, 2005/2006 } \\
\hline Treatments & No & N1 & $\mathbf{N 2}$ & N3 & Mean \\
\hline Rainfed & 316.7 & 300.0 & 366.7 & 600.0 & 395.8 \\
\hline 10 days & 733.3 & 1600.0 & 1467.0 & 3167.0 & $\mathbf{1 7 4 2 . 0}$ \\
\hline 15 days & 600.0 & 783.3 & 900.0 & 1250.0 & 883.3 \\
\hline 30 days & 550.0 & 400.0 & 483.3 & 1050.0 & 620.8 \\
\hline Mean & 550.0 & 770.8 & 804.2 & 1517.0 & \\
\hline $\begin{array}{l}\text { L.S.D. at } 0.05 \text { for: } \\
\text { Irrigation intervals (A) } \\
\text { N fertilization rate (B) } \\
\text { Interaction }(\mathrm{AXB})\end{array}$ & $\begin{array}{l}214.8 \\
214.8 \\
429.5\end{array}$ & & & & \\
\hline
\end{tabular}


Table (3): Effect of irrigation intervals and nitrogen fertilization on dry weight (g)/ plant of Ricinus communis L. during 2004/2005 and 2005/2006 seasons.

\begin{tabular}{|c|c|c|c|c|c|}
\hline \multirow{2}{*}{$\begin{array}{c}\text { Nitrogen rates } \\
\text { Irrigation treatments }\end{array}$} & \multicolumn{5}{|c|}{ First season, 2004/2005 } \\
\hline & No & N1 & $\mathbf{N} 2$ & $\mathbf{N 3}$ & Mean \\
\hline Rainfed & 52.83 & 64.51 & 53.76 & 104.1 & 68.80 \\
\hline 10 days & 154.8 & 321.5 & 261.4 & 619.4 & 339.28 \\
\hline 15 days & 117.1 & 138.7 & 131.6 & 211.6 & 149.75 \\
\hline 30 days & 59.35 & 72.92 & 75.87 & 198.0 & 101.54 \\
\hline Mean & 96.02 & 149.41 & 130.64 & 283.28 & \\
\hline $\begin{array}{l}\text { L.S.D. at } 0.05 \text { for: } \\
\text { Irrigation intervals (A) } \\
\text { N fertilization rate (B) } \\
\text { Interaction } \quad(\mathrm{AXB})\end{array}$ & $\begin{array}{l}62.42 \\
62.42 \\
124.80\end{array}$ & & & & \\
\hline \multicolumn{6}{|c|}{ Second season, 2005/2006 } \\
\hline Treatments & No & N1 & $\mathbf{N 2}$ & N3 & Mean \\
\hline Rainfed & 54.24 & 62.27 & 57.19 & 115.3 & 72.25 \\
\hline 10 days & 156.8 & 350.5 & 286.4 & 689.5 & 370.80 \\
\hline 15 days & 122.4 & 142.0 & 136.6 & 234.7 & 158.93 \\
\hline 30 days & 99.20 & 73.59 & 75.73 & 201.3 & 112.46 \\
\hline Mean & 108.16 & 157.09 & 138.98 & 310.20 & \\
\hline $\begin{array}{l}\text { L.S.D. at } 0.05 \text { for: } \\
\text { Irrigation intervals (A) } \\
\text { N fertilization rate (B) } \\
\text { Interaction } \\
\text { (AXB) }\end{array}$ & $\begin{array}{c}54.17 \\
54.17 \\
108.30\end{array}$ & & & & \\
\hline
\end{tabular}

$\mathrm{N} 0=$ control. $\quad \mathrm{N} 1=100 \mathrm{~kg} / \mathrm{fed} . / \mathrm{season} . \quad \mathrm{N} 2=200 \mathrm{~kg} / \mathrm{fed} . /$ season. $\quad \mathrm{N} 3=300 \mathrm{~kg} / \mathrm{fed} . / \mathrm{season}$.

Table (4): Effect of irrigation intervals and nitrogen fertilization on seed yield (gm) per plant of Ricinus communis $L$. plants during 2004/2005 and 2005/2006 seasons.

\begin{tabular}{|c|c|c|c|c|c|}
\hline \multirow{2}{*}{$\begin{array}{l}\text { Nitrogen rates } \\
\text { Irrigation } \\
\text { treatments }\end{array}$} & \multicolumn{5}{|c|}{ First season, 2004/2005 } \\
\hline & No & N1 & $\mathbf{N 2}$ & N3 & Mean \\
\hline Rainfed & 8.77 & 16.14 & 4.92 & 36.25 & 16.52 \\
\hline 10 days & 37.87 & 55.77 & 55.93 & 100.0 & 62.39 \\
\hline 15 days & 21.45 & 25.05 & 28.74 & 47.58 & 30.70 \\
\hline 30 days & 24.10 & 14.58 & 13.73 & 34.75 & 21.79 \\
\hline Mean & 23.05 & 27.88 & 25.83 & 54.65 & \\
\hline \multicolumn{6}{|c|}{$\begin{array}{llll}\text { L.S.D. at } 0.05 \text { for: } & & \\
\text { Irrigation intervals } & \text { (A) } & 7.86 \\
\text { N fertilization rate } & \text { (B) } & 7.86 \\
\text { Interaction } \quad(A X B) & 15.73\end{array}$} \\
\hline \multicolumn{6}{|c|}{ Second season, $2005 / 2006$} \\
\hline Treatments & No & N1 & $\mathbf{N 2}$ & $\mathbf{N 3}$ & Mean \\
\hline Rainfed & 8.58 & 16.04 & 4.36 & 36.36 & 16.33 \\
\hline 10 days & 38.33 & 56.11 & 56.13 & 101.20 & 62.95 \\
\hline 15 days & 22.21 & 27.19 & 28.75 & 48.42 & 31.64 \\
\hline 30 days & 23.79 & 14.41 & 13.63 & 34.67 & 21.63 \\
\hline Mean & 23.23 & 28.44 & 25.72 & 55.17 & \\
\hline $\begin{array}{l}\text { L.S.D. at } 0.05 \text { for: } \\
\text { Irrigation intervals (A) } \\
\mathbf{N} \text { fertilization rate }(\mathrm{B}) \\
\text { Interaction } \quad \text { (AXB) }\end{array}$ & $\begin{array}{l}9.31 \\
9.31 \\
18.62\end{array}$ & & & & \\
\hline
\end{tabular}


irrigation intervals and nitrogen fertilizer rates on the seed yield/plant, it is clear that, plants irrigated every 10 days and fertilized with the highest rate of nitrogen produced the highest seed yield/plant ( 100.00 and $101.20 \mathrm{gm} /$ plant in the two seasons, respectively). Also, using either low or medium nitrogen rate combined with irrigation every 10 days enhanced seed yield/plant compared to the other interactions. Whereas plants irrigated with rainfed system and fertilized with (N2) gave the lowest seed yield/ plant (4.92 and 4.36 gm/plant) in the first and second seasons, respectively.

\subsubsection{Seed index (weight of 100 seeds)}

The data in Table (5) show that short watering intervals resulted in the best seed index (weight of 100 seeds) in both seasons. Prolonging the irrigation intervals from 10 days to 15 days caused a reduction in seed index in both seasons compared with the shortest irrigation interval (every 10 days), while irrigation every 30 days had no significant effect on seed index in both seasons compared with the rainfed system. These results are in accordance with the findings of Stafford and Mc Michael (1991) on guar. Bhosekar (1992) on Ricinus communis cv. Bhagya and Aruna, Firake et al. (1999) on castor (Ricinus communis) cv. GAU CH-1, Mohamed (2000) on Carum carvi, Osman (2000) on coriander, Attia (2003) on guar, Akbarinia et al. (2005) on Nigella sativa, Nagabhushanam and Raghavaiah (2005) on castor bean.

Concerning the effect of fertilization treatments, the data in Table (5) show that, there was insignificant effect due to applying low and medium levels of nitrogen on seed index compared to the unfertilized plants in both seasons. On the other hand, using the highest level of nitrogen (N3) significantly increased seed index in both seasons compared with unfertilized control. Similar results were obtained by Akbari et al. (2001), Kadam et al. (2006), Lakshmi and Reddy (2006), Silva et al., (2007), Tank et al. (2007) and Venugopal et al. (2007)on castor bean plants.

Regarding the combined effects of irrigation intervals and nitrogen fertilization rates, the results showed that, the combinations of irrigation every 10 or 15 days and different levels of $\mathrm{N}$ fertilizer gave a better seed index than the other combinations. Irrigation every 15 days and fertilization with the high level of nitrogen gave the highest seed index in the two seasons. Whereas rainfed system combined with $\mathrm{N} 2$ gave the lowest seed index in both two seasons.

\subsection{Fixed oil production}

\subsubsection{Fixed oil percentage}

The data presented in Table (6) show that, irrigation intervals had a significant effect on the fixed oil percentages in both two seasons. In the first season, fixed oil percentages obtained due to irrigation intervals every 10,20 and 30 days were (38.84, 40.13 and $35.40 \%)$ compared with $30.31 \%$ for rainfed plants. While in the second season, the averages of fixed oil percentages were $37.69,38.79$ and $35.97 \%$ ) for the irrigation intervals every 10,20 and 30 days, respectively compared with $42.38 \%$ for the rainfed plants. Similar results were obtained by Nagabhushanam and Raghavaiah (2005) on castor hybrid DCH-177 (Deepak) grown under four irrigation regimes (irrigation at 15-days intervals and irrigation at IW/CPE [irrigation water/cumulative pan evaporation ratio] of $0.4,0.6$ and 0.8 ). They showed that oil content was not significantly influenced by irrigation regimes.

Concerning the effect of nitrogen fertilization treatments, the data in Table (6) show that, in the first and second seasons, nitrogen fertilization treatments significantly increased fixed oil percentages compared with the control, except nitrogen fertilization at a medium rate $(\mathrm{N} 2)$ in the second season which decreased fixed oil percentage compared with the control treatment. The highest rate of nitrogen fertilization gave the highest values in both seasons. Similar results were obtained by Mathukia and Modhwadia (1995) on castor bean, they found that, seed oil content decreased with an increase in $\mathrm{N}$ application. On the other hand, Lakshmi and Reddy (2006) and Tank et al. (2007) on castor bean, they showed that, oil content was not significantly influenced by the different $\mathrm{N}$ rates.

Regarding the effect of the interaction between irrigation intervals and nitrogen fertilizer rates on fixed oil percentages, it is clear that, plants irrigated every 15 days combined with the highest rate of nitrogen (N3) produced the highest fixed oil percentage $(45.82 \%)$ during the first season. Whereas rainfed combined with nitrogen fertilizer at ( N2) produced the lowest fixed oil percentage in the first season $(18.11 \%)$. In the second season rainfed combined with $(\mathrm{N} 3)$ nitrogen fertilization treatment produced the highest fixed oil percentage $(48.84 \%)$. While irrigation every 30 days combined with nitrogen fertilization at the medium rate $(\mathrm{N} 2)$ gave the lowest fixed oil percentage $(29.79 \%)$.

\subsubsection{Fixed oil yield per plant and per feddan}

It is evident from the data presented in Tables (7 and 8) that irrigation intervals had a significant 
Table (5): Effect of irrigation intervals and nitrogen fertilization on seed index ( weight of 100 seeds (gm) of Ricinus communis L. plants during 2004/2005 and 2005/2006 seasons.

\begin{tabular}{|c|c|c|c|c|c|}
\hline \multirow{2}{*}{$\begin{array}{r}\text { Nitrogen rates } \\
\text { Irrigation treatments }\end{array}$} & \multicolumn{5}{|c|}{ First season, 2004/2005 } \\
\hline & No & N1 & $\mathbf{N} 2$ & N3 & Mean \\
\hline Rainfed & 34.03 & 30.71 & 23.28 & 35.75 & 30.94 \\
\hline 10 days & 37.38 & 33.95 & 36.61 & 38.72 & 36.67 \\
\hline 15 days & 29.68 & 32.11 & 37.01 & 38.98 & 34.44 \\
\hline 30 days & 29.44 & 28.39 & 27.29 & 38.02 & 30.78 \\
\hline Mean & 32.63 & 31.29 & 31.05 & 37.87 & \\
\hline \multicolumn{6}{|c|}{ 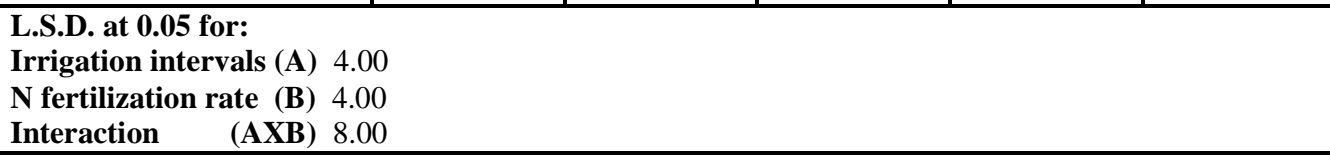 } \\
\hline \multicolumn{6}{|c|}{ Second season, $2005 / 2006$} \\
\hline Treatments & No & N1 & $\mathrm{N} 2$ & N3 & Mean \\
\hline Rainfed & 34.87 & 31.98 & 23.75 & 36.12 & 31.68 \\
\hline 10 days & 37.38 & 34.62 & 36.88 & 38.26 & 36.78 \\
\hline 15 days & 28.73 & 33.38 & 36.88 & 39.14 & 34.53 \\
\hline 30 days & 29.57 & 28.36 & 27.24 & 38.90 & 31.02 \\
\hline Mean & 32.63 & 32.09 & 31.18 & 38.10 & \\
\hline $\begin{array}{l}\text { L.S.D. at } 0.05 \text { for: } \\
\text { Irrigation intervals (A) } \\
\text { N fertilization rate (B) } \\
\text { Interaction }(\mathrm{AXB})\end{array}$ & $\begin{array}{l}33 \\
33 \\
.65\end{array}$ & & & & \\
\hline
\end{tabular}

Table (6): Effect of irrigation intervals and nitrogen fertilization on fixed oil percentage of Ricinus communis L. plants during 2004/2005 and 2005/2006 seasons.

\begin{tabular}{|c|c|c|c|c|c|}
\hline \multirow{2}{*}{$\begin{array}{r}\text { Nitrogen rates } \\
\text { Irrigation treatments }\end{array}$} & \multicolumn{5}{|c|}{ First season, 2004/2005 } \\
\hline & N0 & N1 & N2 & N3 & Mean \\
\hline Rainfed & 35.67 & 29.38 & 18.11 & 38.06 & 30.31 \\
\hline 10 days & 32.12 & 42.67 & 41.35 & 39.23 & 38.84 \\
\hline 15 days & 31.39 & 43.31 & 40.00 & 45.82 & 40.13 \\
\hline 30 days & 32.50 & 29.84 & 36.86 & 42.41 & 35.40 \\
\hline Mean & 32.92 & 36.30 & 34.08 & 41.38 & \\
\hline \multicolumn{6}{|c|}{$\begin{array}{l}\text { L.S.D. at } 0.05 \text { for: } \\
\text { Irrigation intervals }\end{array}$} \\
\hline \multicolumn{6}{|c|}{ Second season, 2005/2006 } \\
\hline Treatments & No & N1 & N2 & N3 & Mean \\
\hline Rainfed & 38.73 & 42.74 & 39.19 & 48.84 & 42.38 \\
\hline 10 days & 35.74 & 43.00 & 38.87 & 33.14 & 37.69 \\
\hline 15 days & 39.38 & 32.49 & 42.00 & 41.29 & 38.79 \\
\hline 30 days & 37.59 & 38.45 & 29.79 & 38.07 & 35.97 \\
\hline Mean & 37.86 & 39.17 & 37.46 & 40.33 & \\
\hline $\begin{array}{l}\text { L.S.D. at } 0.05 \text { for: } \\
\text { Irrigation intervals (A) } \\
\text { N fertilization rate (B) } \\
\text { Interaction } \quad \text { (AXB) }\end{array}$ & & & & & \\
\hline
\end{tabular}

$\mathrm{N} 0=$ control. $\quad \mathrm{N} 1=100 \mathrm{~kg} / \mathrm{fed} . / \mathrm{season} . \quad \mathrm{N} 2=200 \mathrm{~kg} / \mathrm{fed} . / \mathrm{season} . \quad \mathrm{N} 3=300 \mathrm{~kg} / \mathrm{fed} . / \mathrm{season}$.


Table (7): Effect of irrigation intervals and nitrogen fertilization on oil yield (ml)/ plant of Ricinus communis $\mathbf{L}$. during 2004/2005 and 2005/2006 seasons.

\begin{tabular}{|c|c|c|c|c|c|}
\hline \multirow{2}{*}{$\begin{array}{r}\text { Nitrogen rates } \\
\text { Irrigation treatments }\end{array}$} & \multicolumn{5}{|c|}{ First season, 2004/2005 } \\
\hline & No & N1 & $\mathbf{N} 2$ & $\mathbf{N 3}$ & Mean \\
\hline Rainfed & 3.130 & 4.743 & 0.890 & 13.80 & 5.640 \\
\hline 10 days & 12.16 & 23.80 & 23.13 & 39.23 & 24.58 \\
\hline 15 days & 6.727 & 10.85 & 11.49 & 21.80 & 12.72 \\
\hline 30 days & 7.830 & 4.347 & 5.057 & 14.74 & 7.992 \\
\hline Mean & 7.463 & 10.93 & 10.14 & 22.39 & \\
\hline \multicolumn{6}{|c|}{$\begin{array}{lll}\text { L.S.D. at } \mathbf{0 . 0 5} \text { for: } & & \\
\text { Irrigation intervals } & \text { (A) } & 3.05 \\
\mathbf{N} \text { fertilization rate } & \text { (B) } & 3.05 \\
\text { Interaction } & \text { (AXB) } & 6.11 \\
\end{array}$} \\
\hline \multicolumn{6}{|c|}{ Second season, $2005 / 2006$} \\
\hline Treatments & No & N1 & $\mathbf{N 2}$ & N3 & Mean \\
\hline Rainfed & 3.320 & 6.857 & 1.710 & 17.76 & 7.411 \\
\hline 10 days & 13.70 & 24.13 & 21.82 & 33.55 & 23.30 \\
\hline 15 days & 8.743 & 8.837 & 12.08 & 19.99 & 12.41 \\
\hline 30 days & 8.943 & 5.540 & 4.060 & 13.20 & 7.936 \\
\hline Mean & 8.676 & 11.34 & 9.916 & 21.13 & \\
\hline $\begin{array}{l}\text { L.S.D. at } 0.05 \text { for: } \\
\text { Irrigation intervals (A) } \\
\text { N fertilization rate (B) } \\
\text { Interaction } \quad(\mathrm{AXB})\end{array}$ & & & & & \\
\hline
\end{tabular}

Table (8): Effect of irrigation intervals and nitrogen fertilization on oil yield per feddan (L.) of Ricinus communis $\mathbf{L}$. plants during 2004/2005 and 2005/2006 seasons.

\begin{tabular}{|c|c|c|c|c|c|}
\hline \multirow{2}{*}{$\begin{array}{l}\text { Nitrogen rates } \\
\text { Irrigation } \\
\text { treatments }\end{array}$} & \multicolumn{5}{|c|}{ First season, 2004/2005 } \\
\hline & No & N1 & N2 & N3 & Mean \\
\hline Rainfed & 12.51 & 18.97 & 3.563 & 55.19 & 22.56 \\
\hline 10 days & 48.66 & 95.19 & 92.51 & 156.9 & 98.32 \\
\hline 15 days & 26.93 & 43.40 & 45.97 & 87.20 & 50.87 \\
\hline 30 days & 31.33 & 17.40 & 20.23 & 58.94 & 31.98 \\
\hline Mean & 29.85 & 43.74 & 40.57 & 89.57 & \\
\hline \multirow{2}{*}{\multicolumn{6}{|c|}{$\begin{array}{llll}\text { L.S.D at } 0.05 \text { for: } & & \\
\text { Irrigation intervals } & \text { (A) } & 12.22 \\
\text { N fertilization rate } & \text { (B) } & 12.22 \\
\text { Interaction } & \text { (AXB) } & 24.43 \\
\end{array}$}} \\
\hline & & & & & \\
\hline Treatments & No & N1 & N2 & N3 & Mean \\
\hline Rainfed & 13.28 & 27.43 & 6.837 & 71.03 & 29.65 \\
\hline 10 days & 54.79 & 96.51 & 87.26 & 134.2 & 93.19 \\
\hline 15 days & 34.98 & 35.34 & 48.31 & 79.97 & 49.65 \\
\hline 30 days & 35.77 & 22.16 & 16.24 & 52.80 & 31.74 \\
\hline Mean & 34.70 & 45.36 & 39.66 & 84.50 & \\
\hline $\begin{array}{l}\text { L.S.D. at } 0.05 \text { for: } \\
\text { Irrigation intervals (A) } \\
\text { N fertilization rate (B) } \\
\text { Interaction } \quad(\mathbf{A X B})\end{array}$ & & & & & \\
\hline
\end{tabular}


Table (9): Effect of irrigation intervals and nitrogen fertilization on total carbohydrates percentages

(\%) in dry leaves of Ricinus communisL. plants during 2004/2005 and 2005/2006 seasons.

\begin{tabular}{|c|c|c|c|c|c|}
\hline \multirow{2}{*}{$\begin{array}{r}\text { Nitrogen rates } \\
\text { Irrigation treatments }\end{array}$} & \multicolumn{5}{|c|}{ First season, 2004/2005 } \\
\hline & No & N1 & N2 & N3 & Mean \\
\hline Rainfed & 21.67 & 23.50 & 25.27 & 33.11 & 25.89 \\
\hline 10 days & 31.75 & 41.51 & 50.23 & 56.65 & 45.03 \\
\hline 15 days & 23.50 & 24.54 & 33.73 & 52.53 & 33.57 \\
\hline 30 days & 19.69 & 21.72 & 26.89 & 36.19 & 26.12 \\
\hline Mean & 24.15 & 27.82 & 34.03 & 44.62 & \\
\hline \multicolumn{6}{|c|}{ Second season, $2005 / 2006$} \\
\hline Treatments & No & N1 & $\mathbf{N 2}$ & N3 & Mean \\
\hline Rainfed & 23.55 & 24.54 & 25.69 & 38.69 & 28.12 \\
\hline 10 days & 36.97 & 48.98 & 50.18 & 54.62 & 47.69 \\
\hline 15 days & 26.68 & 30.91 & 36.03 & 52.58 & 36.55 \\
\hline 30 days & 23.03 & 24.07 & 26.58 & 30.39 & 26.02 \\
\hline Mean & 27.56 & 32.12 & 34.62 & 44.07 & \\
\hline
\end{tabular}

Table (10): Effect of irrigation intervals and nitrogen fertilization on nitrogen percentages in dry leaves of Ricinus communis $\mathbf{L}$. plants during 2004/2005 and 2005/2006 seasons.

\begin{tabular}{|c|c|c|c|c|c|}
\hline \multirow{2}{*}{$\begin{array}{c}\text { Nitrogen rates } \\
\text { Irrigation treatments }\end{array}$} & \multicolumn{5}{|c|}{ First season, 2004/2005 } \\
\hline & No & N1 & $\mathbf{N} 2$ & $\mathbf{N 3}$ & Mean \\
\hline Rainfed & 0.32 & 0.37 & 0.49 & 0.56 & 0.43 \\
\hline 10 days & 1.69 & 1.54 & 1.72 & 1.27 & 1.55 \\
\hline 15 days & 0.22 & 0.37 & 0.59 & 1.91 & 0.77 \\
\hline 30 days & 0.22 & 0.54 & 0.51 & 0.49 & 0.44 \\
\hline Mean & 0.61 & 0.70 & 0.83 & 1.06 & \\
\hline \multicolumn{6}{|c|}{ Second season, $2005 / 2006$} \\
\hline Treatments & No & N1 & N2 & N3 & Mean \\
\hline Rainfed & 0.51 & 0.54 & 0.66 & 0.64 & 0.59 \\
\hline 10 days & 1.42 & 1.10 & 1.32 & 1.27 & 1.28 \\
\hline 15 days & 0.54 & 0.47 & 0.83 & 1.74 & 0.89 \\
\hline 30 days & 0.61 & 0.69 & 0.83 & 0.64 & 0.69 \\
\hline Mean & 0.77 & 0.70 & 0.91 & 1.07 & \\
\hline
\end{tabular}

effect on fixed oil yield/ plant and per feddan in both seasons. Irrigation every 10 days produced the highest increase in fixed oil yield per plant and per feddan in the two seasons. Irrigation every 15 and 30 days significantly increased fixed oil yield/ plant and per fed. in the two seasons. Whereas the lowest oil yield per plant and per fed. were obtained for the rainfed treatment in the first and second seasons. Firake et al. (1999) on castor bean, reported that daily application of water at $75 \%$ Ep through drip irrigation was the best treatment for oil yields which were increased by 50 to $51 \%$, compared with border irrigation.

Nitrogen fertilization at different rates had a significant effect on oil yield/ plant and per fed. in both seasons. Supplying plants with the highest nitrogen rate (N3) resulted in the highest oil yield/plant and per fed. in the first and second seasons. Nitrogen fertilization at the low rate significantly increased fixed oil yield/ plant and per fed. in the first season compared to the control, while nitrogen fertilization at the low or medium rates insignificantly increased fixed oil yield per plant and per fed. In the second season compared with unfertilized control gave the lowest fixed oil yield/ plant and per fed. These increments were due to the effect of nitrogen fertilization on increasing the fixed oil percentage and seed yield/ plant and per fed. Similar results were obtained by Lakshmi and Reddy (2006) on castor bean. They showed that, oil content was not significantly influenced by the different $\mathrm{N}$ rates, whereas oil yield in seed and stalks increased significantly with increase in $\mathrm{N}$ rate up to $80 \mathrm{~kg} / \mathrm{ha}$. The difference between 80 and $120 \mathrm{~kg} \mathrm{~N} /$ ha was not significant. 
Regarding the combined effect between irrigation intervals and nitrogen fertilization rates, it was observed that the highest fixed oil yield/ plant and per fed. were obtained due to irrigation every 10 days combined with the highest nitrogen rate (N3) in the two seasons. Whereas, the lowest fixed oil yield/ plant and per fed. in the two seasons were produced by plants that were rainfed and supplied with nitrogen fertilization at the rate of (N2).

\subsection{Chemical composition}

\subsubsection{Total carbohydrate percentages}

Data in Table (9) show that plants irrigated every 10 days had the highest total carbohydrates percentages in both seasons followed by plants irrigated every 15 days, compared with rainfed plants or the plants irrigated at long intervals (every 30 days) which gave the lowest total carbohydrate percentages in the first and second seasons, respectively. Similar results were obtained by Hammam (1996) on anise (Pimpinella anisum), Youssef (1997) on Cuminum cyminum, Osman (2000) on coriander and Attia (2003) on guar. They showed that irrigation at short intervals significantly increased total carbohydrate contents.

Concerning the effect of nitrogen fertilizer rate on the total carbohydrate content in the leaves, the highest values were obtained from plants fertilized with the highest $\mathrm{N}$ rate ( N3) in the two seasons. Increasing nitrogen fertilizer rate gradually increased total carbohydrate percentages compared with unfertilized plants which gave the lowest values in both seasons. These results are in harmony with those obtained by Hammam (1996) on Pimpinella anisum, who showed that nitrogen application increased total carbohydrate contents. Regarding the interaction effects between irrigation intervals and nitrogen fertilizer rates, the highest total carbohydrate content in the leaves was $56.65 \%$ in the first season, resulted from the irrigation every 10 days combined with high nitrogen rate, followed by irrigation every 15 days with high nitrogen rate, and irrigation every 10 days with a medium nitrogen rate. These last two treatments gave values of 52.53 and $50.23 \%$, respectively. On the other hand, the lowest total carbohydrate content $(19.69 \%)$ resulted from combining irrigation every 30 days with nonitrogen fertilization. In the second season, the highest total carbohydrate content (54.62 \%) resulted from the interaction between irrigation every 10 days and the highest nitrogen fertilizer rate, followed by the interaction between irrigation every 15 days with the highest nitrogen rate and irrigation every 10 days with medium nitrogen rate; the values were 52.58 and $50.18 \%$, respectively. On the other hand, the lowest total carbohydrate content $(23.03 \%)$ resulted from combining irrigation every 30 days with nonitrogen fertilization.

\subsubsection{Nitrogen percentage}

Data in Table (10) showed that the plants irrigated every 10,15 and 30 days the had higher nitrogen percentages in the leaves in both seasons, compared with rainfed plants. Irrigation every 10 days gave the highest nitrogen contents in the leaves in both seasons. Similar results were obtained by Youssef (1997) on cumin, Sidky et al. (1998) on roselle, Osman (2000) on coriander and Attia (2003) on guar plants. They stated that short irrigation intervals increased nitrogen contents.

Concerning the effect of nitrogen fertilizer rates on nitrogen percentages in the leaves, it is clear that, in most cases, increasing nitrogen fertilization rate gradually increased nitrogen contents in the leaves in both seasons. Nitrogen application at the highest rate $(\mathrm{N} 3)$ gave the highest $\mathrm{N}$ contents as compared with the unfertilized control in both seasons. The highest mean values were 1.06 and $1.07 \%$ in the first and second seasons, respectively compared with 0.61 and $0.77 \%$ in the leaves of unfertilized plants in both seasons, respectively.

These results are in agreement with those obtained by Mathukia and Modhwadia (1995) and Lakshmi and Reddy (2006) on castor bean. They showed that $\mathrm{N}$ contents was increased significantly with increasing nitrogen rate .

Regarding the effect of interaction between irrigation intervals and nitrogen fertilizer rates, data in Table (10) indicate that the highest nitrogen contents in the leaves resulted from irrigation every 15 days combined with the highest nitrogen rate $(\mathrm{N} 3)$ in both seasons, whereas the lowest nitrogen content in the first season resulted from irrigation every 30 days combined with no-nitrogen fertilizer, while the lowest nitrogen content in the second season resulted from combining irrigation every 15 days with the low nitrogen fertilizer rate (N1).

In conclusion to obtain the best results on vegetative growth, seed production, fixes oil production and chemical constituents of castor bean plant in sandy soil we recommended the use of irrigation every 10 days and nitrogen fertilization at $300 \mathrm{~kg} / \mathrm{fed} . / \mathrm{season}$.

\section{REFERENCES}

A.O.A.C (1995). Association of Official Analytical Chemists Methods of Analysis. 
$12^{\text {th }}$ Ed. Washington, D.C.

Akbari K. N., Sutaria, G. S., Patel P. R. and Yusufzai A. S. (2001). Response of castor (Ricinus communis L.) to nitrogen and phosphorus under rainfed condition. Advances in Plant Sciences. 14 (2):445-451.

Akbarinia A., Khosravifard M., Ashoorabadi E. S. and Babakhanlou P. (2005). Effects of irrigation interval on the yield and agronomic characteristics of black cumin (Nigella sativa). Iranian Journal of Medicinal and Aromatic Plants Research. 21(1): 65-73.

Attia D. M. G. (2003). Physiological studies on guar plants in sandy soil. M. Sc. Thesis, Fac. Agric., El Arish, Suez Canal Univ., Egypt.

Bhosekar V. K. (1992). Effect of irrigation, nitrogen and plant density on yield attributes and yield of castor (Ricinus communis) varieties. Indian Journal of Agronomy, 37 (1): 203-205.

Chaplin M. F. and Kennedy J. F. (1994). Carbohydrate Analysis, a Practical Approach. Oxford Univ. Press. pp. 31.

Devi M. U., Santaiah V., Rao S. R., Rao A. P and Rao M. S. (1990). Interaction of conservation tillage and nitrogen fertilization on growth and yield of rainfed castor. Journal of Oil Seeds Research, 7(1): 98-105.

Duke J. A and Wain K. K. (1981): Medicinal Plants of the World. Computer index with more than 85,000 entries. 3 vols. Longman group UK Limited.

El-Shafie S. A., Eraki M. A., Mazroa M. M and Saafan S. A. (1994). Physiological studies on roselle plant. Zagazig J. Agic. Res., 21 (1): 227-239.

Firake N.N., Shinde S.H. and Magar S.S. (1999). Drip irrigation scheduling for castor in sandy clay loam. Journal of Maharashtra Agricultural Universities. 23(3): 280-282.

Hammam K. A. M. (1996). Effect of nitrogenous fertilization and irrigation on growth, yield and active constituents of anise (Pimpinella anisum L.) plants. M. Sc. Thesis, Fac. Agric., Cairo Univ., Egypt.

Hikwa D. and Mugwira L.M. (1997). Response of castor cultivar Hale to rate and method of nitrogen fertilizer application in different environments of Zimbabwe. African Crop Science Journal. 5(2): 175-188.

Ishwar S. and Ganpat S. (1992). Schedule of irrigation for 'Aruna' castor (Ricinus communis). Indian Journal of Agricultural Sciences. 62(9): 614-615.

Jackson M.L. (1973). Soil analysis. Printice-Holl of India, New Delhi pp. 144-197.

Kadam P. S., Sugave G. T. and Jadhao A. S. (2006). Response of castor genotypes to fertilizer application in vertisols. Annals of Plant Physiology. 20(1): 160-161.

Khandelwal S. K., Gupta N. K. and Nagda C. L. (2003). Effect of application of different levels of nitrogen and phosphorus on growth, yield and quality of henna (Lawsonia inermis). Journal of Medicinal and Aromatic Plant Sciences. 25(4): 984-988.

Lakshmi Y. S. and Reddy A. S. (2006). Effect of nitrogen and phosphorus on oil content and nutrient uptake in rabi castor. Research on Crops. 7(2): 423-425.

Mathukia R.K. and Modhwadia M. M. (1993). Response of castor (Ricinus communis L.) to nitrogen and phosphorus. Indian Journal of Agronomy, 38 (1): 152-153.

Mathukia R. K. and Modhwadia M. M.(1995). Influence of different levels of nitrogen and phosphorus on yield and nutrient uptake by castor (Ricinus communis L.). Gujarat Agricultural University Research Journal. 21(1): 149-151.

Mohamed M. I. (2000). Physiological studies on Coriandrum sativum L. and Carum carvi $\mathrm{L}$. plants. Ph. D. Thesis, Fac. Agric., Cairo Univ., Egypt.

Nagabhushanam U. and Raghavaiah C.V. (2005). Seedling date and irrigation effects on the productivity and oil quality of post-monsoon grown castor, Ricinus communis L. in Alfisols. Journal of Oil Seeds Research. 22(1): 206-208.

Naguib N. Y. and Husssein M. S. (1995). Response of Hibiscus sabdariffa L. to irrigation intervals under foliar spraying with mepiquate chloride (Mc). Zagazig J. Agric. Res., 22(6): 1437:1446.

Osman Y. A. H. (2000). Possibility of production of Coriander (Coriandrum sativum L) under Sinai conditions. Ph. D. Thesis, Fac. Agric., Cairo Univ., Egypt.

Paikaray R. K., Sarma Y. N. and Dash B. B. (1992). Response of castor to fertilizers in southern Orissa. Orissa Journal of Agricultural Research. 4: (3-4): 206-207.

Patel M. K., Fatteh U. G. and Patel V. J. (1991). Effect of nitrogen and its time of application on yield of castor Gauch-1 (Ricinus communis L.) under irrigated condition in North Gujarat. Gujarat Agricultural University Research Journal. 17(1): 27-29.

Pregl H. (1945). Quantitative Organic Microanalysis $4^{\text {th }}$ edition Churchill London.

Reddy G. S., Rao D. G., Venkateswarlu S. and Maruthi V. (1996). Drought management options for rainfed castor in alfisols. Journal of Oil Seeds Research. 13 (2): 200-207. 
Reed C. F. (1976). Information summaries on 1000 economic plants. Typescripts submitted to the USDA.

Sidky M. A., Harridi I. and Mousa A. I. (1998). The use of chemical and organic fertilizers for the nutrition of roselle (Hibiscus sabdariffa L.) plants irrigated at different intervals. Egyptian Journal of Applied Science, 13 (2): 138-160.

Silva T. R. B., Leite V. E., Silva A. R. B. and Viana, L. H. (2007). Nitrogen sidedressing fertilization on castor plant in no tillage system. Pesquisa Agropecuaria Brasileira. 42(9): 1357-1359.

Snedecor G. W. and Cochran W. G. (1982). Statistical Methods. The Iowa State Univ. Press, Ames, Jowa: 507 pp.

Stafford R. E. and B. L. McMichael (1991). Effect of water stress on yield components in guar. Journal of Agronomy and crop Science, 166(1), 63-68 (Hort. Abst., Vol. 61 (11): 10054).



المجلة العلمية لكلية الزراعة - جامعة القاهرة - المجلا (62) العدد الأول ( يناير 2011):61-49. 